\title{
REGENERATIVE PERFORMANCE OF THE NASA SYMMETRICAL SOLID OXIDE FUEL CELL DESIGN
}

T.L. Cable*, J.A.Setlock, University Toledo, USA; S.C. Farmer, A.J. Eckel, NASA Glenn Research Center, Cleveland, OH;

\begin{abstract}
The NASA Glenn Research Center is developing both a novel cell design (BSC) and a novel ceramic fabrication technique to produce fuel cells predicted to exceed a specific power density of $1.0 \mathrm{~kW} / \mathrm{kg}$. The NASA Glenn cell design has taken a completely different approach among planar designs by removing the metal interconnect and returning to the use of a thin, doped $\mathrm{LaCrO}_{3}$ interconnect. The cell is structurally symmetrical. Both electrodes support the thin electrolyte and contain micro-channels for gas flow-- a geometry referred to as a bi-electrode supported cell or BSC. The cell characteristics have been demonstrated under both SOFC and $\mathrm{SOE}$ conditions. Electrolysis tests verify that this cell design operates at very high electrochemical voltage efficiencies (EVE) and high $\mathrm{H}_{2} \mathrm{O}$ conversion percentages, even at the low flow rates predicted for closed loop systems encountered in unmanned aerial vehicle (UAV) applications. For UAVs the volume, weight and the efficiency are critical as they determine the size of the water tank, the solar panel size, and other system requirements. For UAVs, regenerative solid oxide fuel cell stacks (RSOFC) use solar panels during daylight to generate power for electrolysis and then operate in fuel cell mode during the night to power the UAV and electronics. Recent studies, performed by NASA for a more electric commercial aircraft, evaluated SOFCs for auxiliary power units (APUs). System studies were also conducted for regenerative RSOFC systems. One common requirement for aerospace SOFCs and RSOFCs, determined independently in each application study, was the need for high specific power density and volume density, on the order of $1.0 \mathrm{~kW} / \mathrm{kg}$ and greater than $1.0 \mathrm{~kW} / \mathrm{L}$. Until recently the best reported performance for SOFCs was $0.2 \mathrm{~kW} / \mathrm{kg}$ or less for stacks. NASA Glenn is working to prototype the light weight, low volume BSC design for such high specific power aerospace applications.
\end{abstract}

\section{INTRODUCTION}

Solid oxide fuel cells (SOFCs) have a significant commercial potential due to their high efficiency, high energy density, and flexible fuel capability, operating on both hydrogen and hydrocarbon-based fuels. SOFCs have had a long development history. The materials and fabrication challenges have delayed technical maturity behind that of proton exchange membrane (PEM) fuel cells. NASA contracted Boeing to perform two studies, the first evaluating an SOFC/Gas Turbine (GT) hybrid system vs. an internal combustion engine, (ICE), system for auxiliary power units (APUs), of about $440 \mathrm{~kW}$ to go in the tail of a commercial airliner, and the second for a high altitude long endurance (HALE) [1] hybrid Fuel Cell/Gas Turbine (GT) or ICE/GT UAV system with a goal of 14-days endurance and generating $56 \mathrm{~kW}$. Both PEM and SOFC were evaluated. In each study, SOFC technology offered superior performance. Due to the higher hybrid system efficiency. An improvement of about 30\%, has been predicted, Figure 1. 


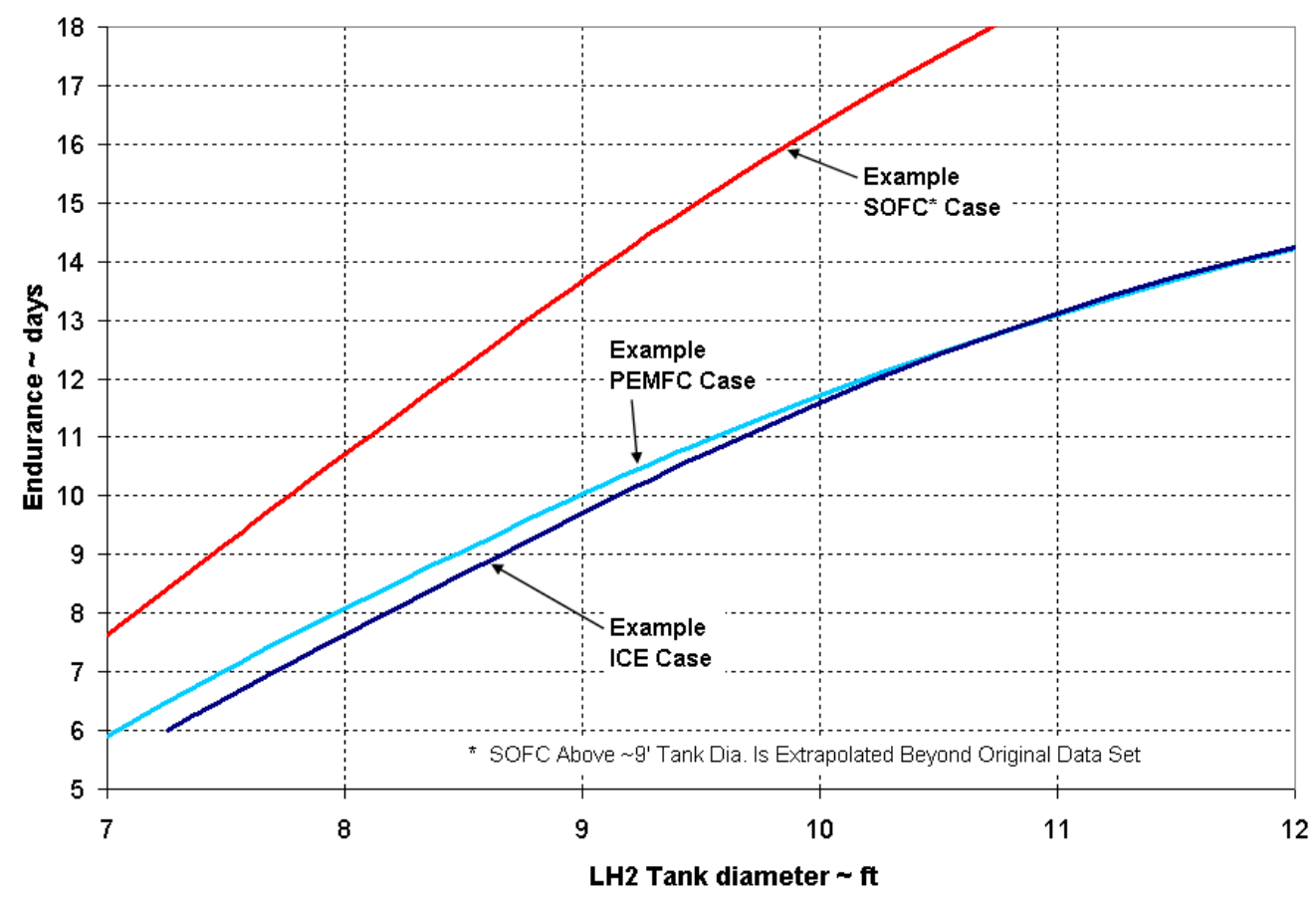

Figure 1. Boeing Contracted Study, goal is a 14-day mission while maintaining a reasonable tank size and weight.

However, each study also identified that the stack must operate at a cell power density greater than $1.4 \mathrm{~W} / \mathrm{cm}^{2}$ and that the stack specific power density should exceed $1.0 \mathrm{~kW} / \mathrm{kg}$. Additional analysis of the data for the $444 \mathrm{~kW}$ APU highlighted the sensitivity to the design and weight of the metal interconnect. By adopting a thin metal foil design, the total stack mass calculated decreased from $1097 \mathrm{~kg}$ to $441 \mathrm{~kg}$, corresponding to a stack power density increase from 0.4 $\mathrm{kW} / \mathrm{kg}$ to $1.0 \mathrm{~kW} / \mathrm{kg}[2]$.

There is considerable challenge in transitioning from the high power densities of small, single cells, to similar performance in a large stack. Figure 2 is illustrative of that challenge. It shows typical data for a commercial company [3] as they scale-up cell technology in four distinct stages. Stage 1) starts with a button cell, approximately $2.5 \mathrm{~cm}$ diameter, $3 \mathrm{~cm}^{2}$ active electrode area, normally tested with high flow rates and very low fuel utilization. Under these ideal conditions, the required $\mathrm{P}_{\text {dens }}=1.4 \mathrm{~W} / \mathrm{cm}^{2}$ is achieved. In stage 2), an intermediate cell size of $\sim$ $7 \mathrm{~cm}$, now large enough to have significant fuel composition gradients, current density and temperature gradients across the cell make conditions non-ideal. The performance drops to about $P_{\text {dens }}=0.9 \mathrm{~W} / \mathrm{cm}^{2}$. In stage 3), the identical cell is now tested with half an interconnect above and below it, making it a one-cell stack or repeat unit. With the additional resistive losses at the interconnect/electrode interfaces there is an additional drop in performance to $\mathrm{P}_{\text {dens }}=0.6$ $\mathrm{W} / \mathrm{cm}^{2}$. Finally in stage 4), the cells are scaled to full commercial size. The stack now 
experiences all of the real challenges and sources of power loss: not all the cells may be perfectly flat, edge seals may not be hermetic, etc., and the performance declines further to $\sim 0.4 \mathrm{~W} / \mathrm{cm}^{2}$, a power density decrease of $\sim 70 \%$ from the original button cell data.

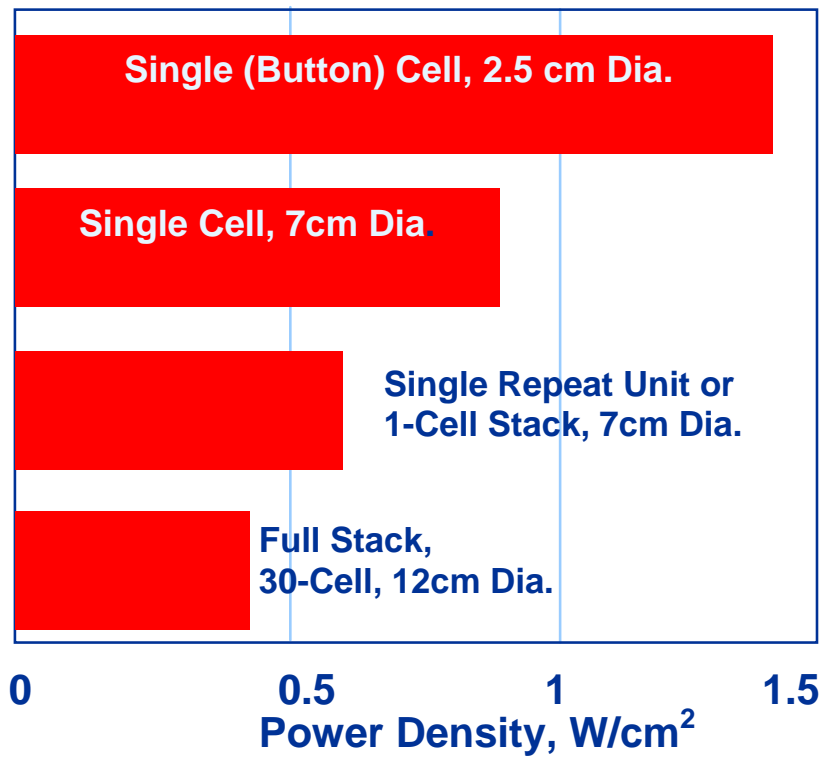

Figure 2. Development stages of technology from small (button) cells to full size stack [3]. Loss in performance due to contact resistance, gas phase composition gradients, etc.

A power density of $0.4 \mathrm{~W} / \mathrm{cm}^{2}$ is good performance for a 30-cell stack, particularly if it can be done reproducibly and with all the cells performing at the same voltage, if the stack can be thermally cycled, and if it has low degradation per 1000 hours of operation. From a review of the technical literature, the reported performance for most kilowatt-size demonstration units operating in the field, the power density achieved is $0.3-0.4 \mathrm{~W} / \mathrm{cm}^{2}$. Unfortunately, models reported in the literature predict that you can build large stacks, with $25 \mathrm{~cm} \mathrm{x} 25 \mathrm{~cm}$ cells, and have them operate at the $1.4 \mathrm{~W} / \mathrm{cm}^{2}$, a performance level achieved only on button cell data as in Figure 2 above to date.

The NASA SOFC team evaluated the trends in Figure 2 and concluded that small improvements in state of the art planar cell technology, particularly with the push to lower the temperature of operation for metal interconnects, in current SOFC technology programs, was not going to lead to the high power densities required by aerospace applications. Since most of the cell weight and volume is associated with the metal interconnects, on the order of $70 \%$, the decision was made to remove the metal interconnect completely. At that same time, NASA was actively pursuing a technique for tape casting called freeze-casting and we adopted use of the gradient porosity of freeze-cast tapes to create a novel cell and stack design.

The NASA Glenn cell design removes the metal interconnect and replaces it with a thin, flat layer of Ca-doped $\mathrm{LaCrO}_{3}$ (LCC) on the order of 30 to 60 microns thick. The cell is structurally symmetrical, with both electrodes supporting the thin electrolyte and containing micro-channels 
for gas diffusion, a bi-electrode supported cell or BSC. The electrodes are made by freezecasting, a modified tape casting technique which creates the many micro-channels in the YSZ electrode green tape as shown in Figure 3. The BSC is both low volume and low weight. Since cells are fabricated of all ceramic materials, cells can operate at higher temperatures, and it makes formation of hermetic, ceramic-to-ceramic seals possible. Removal of the metal interconnects, which alone account for up to $70 \%$ of the weight and volume in many planar designs, provides a dramatic improvement in both the specific power density and volume density. Comparing stacks of cells only, with $100 \mathrm{~cm}^{2}$ active area, operating at $400 \mathrm{~mW} / \mathrm{cm}^{2}$, a standard state-of-the-art anode supported cell and cassette or picture frame-type metal interconnect (a repeat unit) weighs about $199 \mathrm{~g}$ and has a volume of $85 \mathrm{~cm}^{3}$. By comparison, the BSC cell and interconnect repeat unit weighs only $36 \mathrm{~g}$ and has a volume of $10 \mathrm{~cm}^{3}$. The BSC design has the potential to improve the power density by a factor of 5 times, increasing the Specific Power from $0.2 \mathrm{~kW} / \mathrm{kg}$ to $1.09 \mathrm{~kW} / \mathrm{kg}$. The BSC design is also significantly more compact. The Power Density of cells increases significantly, from $0.5 \mathrm{~kW} / \mathrm{L}$ to $4.1 \mathrm{~kW} / \mathrm{L}$.

This paper will focus on the cell and stack design of the BSC. We will also show the test data for the BSC operated as a regenerative cell, report on the high electrochemical voltage efficiency, and discuss why this design is ideally suited to regenerative applications.
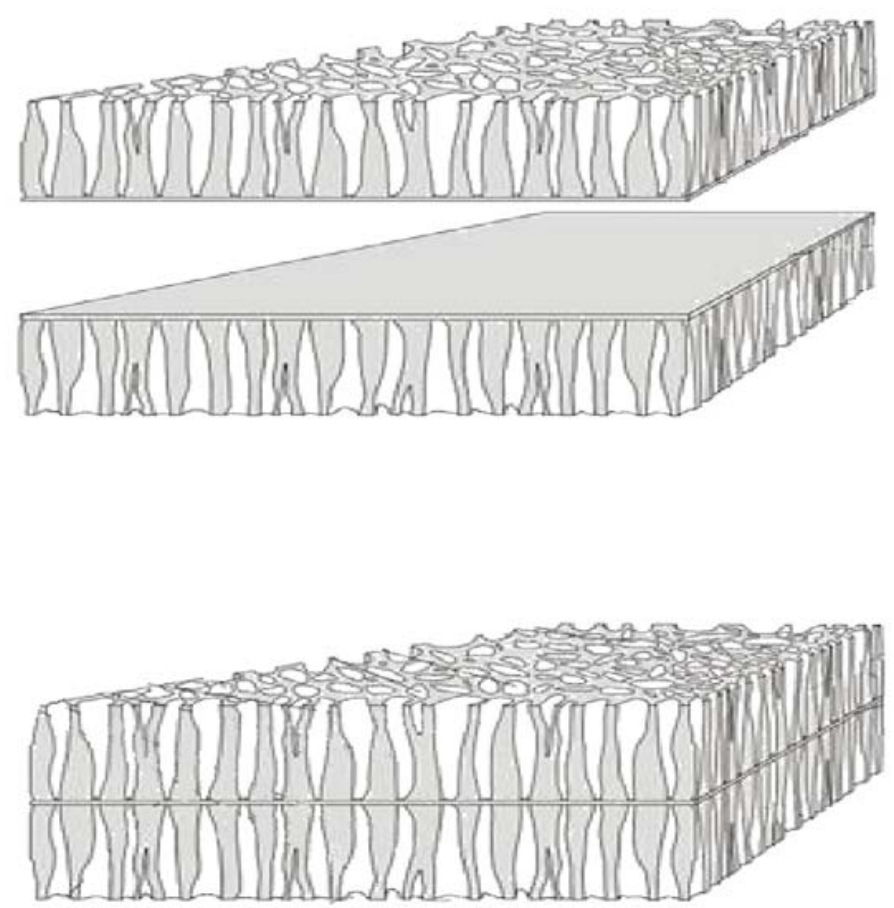

Figure 3: Thin YSZ electrolyte supported between two graded porous scaffolds. 


\section{The Structurally Symmetrical, NASA Bi-supported Cell (BSC) Concept}

In developing the new cell concept, NASA endeavored to address the key challenges and materials issues encountered by the state-of-the-art SOFC designs [4]. These include; power loss resulting from the need to lower the operating temperature, due to poisoning of the cathode (air electrode) by $\mathrm{Cr}$ from metal interconnects; the weight of the interconnect; high cell/metal interconnect contact resistances; and seals. To reach the highest possible power capabilities NASA chose to remain at higher operating temperatures, $850^{\circ} \mathrm{C}$ average across the cell, and to allow parts of the cell to go to higher temperatures. The selected interconnect, a thin conductive Ca-doped $\mathrm{LaCrO}_{3}$ (LCC) or other doped- $\mathrm{LaCrO}_{3}$ ceramic, makes co-firing of a "unitized" stack of cells possible. The technical approach taken by the NASA design for each of the major technical and materials hurdles is shown in Table 1. The key feature of the design concept is the structurally symmetrical cell, which is made by supporting the thin electrolyte on both sides with a porous YSZ support structure. The symmetric design balances mechanical stresses, improves strength upon thermal cycling and simplifies stack manufacture.

Table 1: Comparison of Major Materials Challenges

\begin{tabular}{|c|c|c|}
\hline $\begin{array}{l}\text { Anode Supported Cells with Metal } \\
\text { Interconnects }\end{array}$ & $\begin{array}{l}\text { NASA Glenn BSC all ceramic design and } \\
\text { fabrication advantages }\end{array}$ \\
\hline $\begin{array}{l}\text { Maintaining a thin, dense, YSZ } \\
\text { electrolyte without flaws, } \\
\text { supported on NiO-YSZ cermet, } \\
\text { avoid failure induced by Ni-NiO } \\
\text { oxidation/reduction stresses }\end{array}$ & $\begin{array}{l}\text { Thin YSZ electrolyte is supported by } \\
\text { identical, porous YSZ electrodes on } \\
\text { both sides, providing symmetrically } \\
\text { balanced stresses. }\end{array}$ \\
\hline $\begin{array}{l}\text { Metal to Ceramic Seals perform } \\
\text { well at operating temperature but } \\
\text { thermal cycles a challenge, } \\
\text { allowing some \% of fuel leakage. }\end{array}$ & $\begin{array}{l}\text { Integral YSZ seals are applied in the } \\
\text { green state, matched CTE with the } \\
\text { thin LCC interconnect and sintered } \\
\text { with stack to form hermetic seals }\end{array}$ \\
\hline $\begin{array}{l}\text { Contact resistance between the } \\
\text { metal interconnect/cell, provided } \\
\text { by current collecting coatings, } \\
\text { design must compensate for } \\
\text { curvature of the cells. }\end{array}$ & $\begin{array}{l}\text { Cell and interconnect are sintered } \\
\text { together to form a "unitized” repeat } \\
\text { unit, electrode infiltration ensures } \\
\text { contact between electrode/electrolyte } \\
\text { and electrode/LCC interconnect. }\end{array}$ \\
\hline $\begin{array}{l}\text { Evolution of Cr-species from the } \\
\text { metal interconnect most likely } \\
\text { requires pretreatment and/or } \\
\text { coatings of the interconnect. }\end{array}$ & $\begin{array}{l}\text { LCC interconnect does not evolve Cr- } \\
\text { species, it is stable in SOFC operating } \\
\text { conditions. }\end{array}$ \\
\hline
\end{tabular}

The porous YSZ support structure (scaffold) has graded pores, allowing the gas channels or flow fields to be incorporated into the electrodes rather than the interconnect. This enables use of a 
thin LCC interconnect, significantly reducing the weight of the stack. The graded porosity provides the smallest pores (1-5 microns) at the electrode/electrolyte interface, creating the maximum amount of active interfacial area or triple phase boundary (TPB) once the active electrode materials are infiltrated. The continuous pore channels (tortuosity equivalent to 1 , i.e. a straight channel) then increase in size to approximately 80-100 microns in diameter and serve as gas flow fields or channels for air and fuel. While there are numerous fabrication techniques commonly used in ceramic processing that can generate a graded porous structure [5], NASA pursued freeze casting of tapes, creating columnar pore morphologies in thin film ceramics. The thin electrolyte is deposited between two layers of identical freeze-cast green tape. It is mechanically balanced on either side by the porous YSZ support structures (electrode scaffolds) as shown in Figure 4. At this stage, the single cell consists of only YSZ, no other material, and is symmetrical about the central electrolyte. If sintered at this stage, parts sinter flat as stresses are low and equally balanced. Adding thin LCC layers to the top and bottom of the still does not alter the balanced stresses; parts are flat when removed from the sintering furnace since they are still approximately $93 \%$ by weight YSZ.

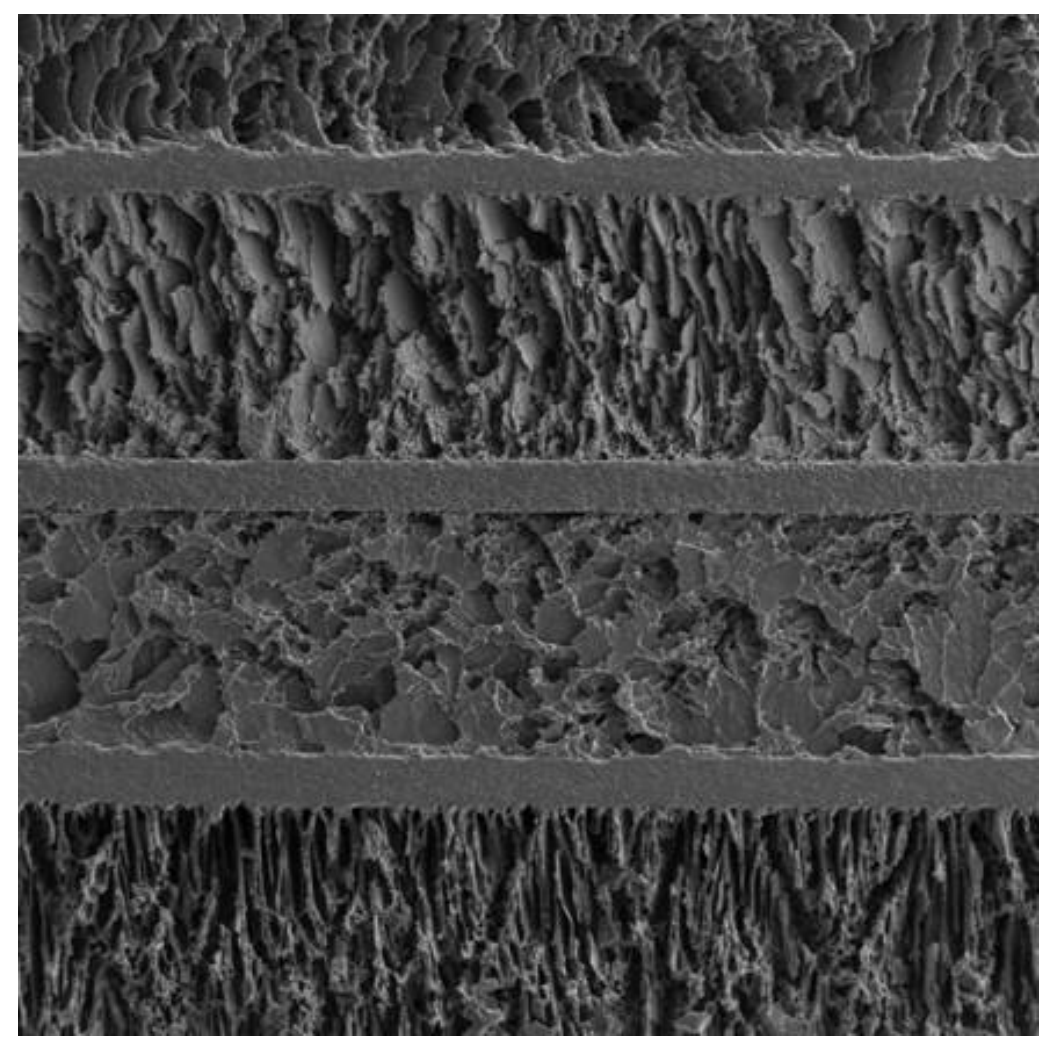

Figure 4. Multi-layer stack of cells showing the $\mathrm{LaCaCrO}_{3}$ interconnect (60 microns), the YSZ layer (60 microns) and showing the 90 degree orientation of the electrode support scaffolds in the X-flow design; the center section shows one full repeat unit from LCC layer to LCC layer. 
Given the iso-material design of the electrolyte and electrode scaffolds, and a $\mathrm{LaCrO}_{3}$ (LCC), interconnect with coefficient of thermal expansion near that of YSZ, BSC cells can be laminated in the green state and co-sintered as one assembly making the fabrication of the BSC repeat unit relatively simple. A thin YSZ ink can be applied wet to form edge seals upon firing, creating a simple cross-flow geometry as shown in Figure 5. Multiple repeat units can be laminated in the green state and fired to produce a stack. In fabricating a number of cells into a stack, only the YSZ and LCC materials are fired in the high-temperature sintering step. Not only is it easier to optimize the sintering and shrinkage rates of only two discrete materials systems with similar thermal expansions, both materials are conducive to $1450-1550^{\circ} \mathrm{C}$ firing schedules. Since the structural base of the cell can be prepared with a single high temperature processing step the "unitized", multi-cell stack can be leak tested and mechanically tested before further processing of electrode materials. At this stage, electrodes may be deposited by liquid or vapor chemistry techniques using the gas flow channels as a delivery path. As the active electrode materials are deposited at the YSZ electrolyte/electrode interface, they also make intimate contact with the LCC interconnect, further minimizing ohmic losses through the repeat unit.

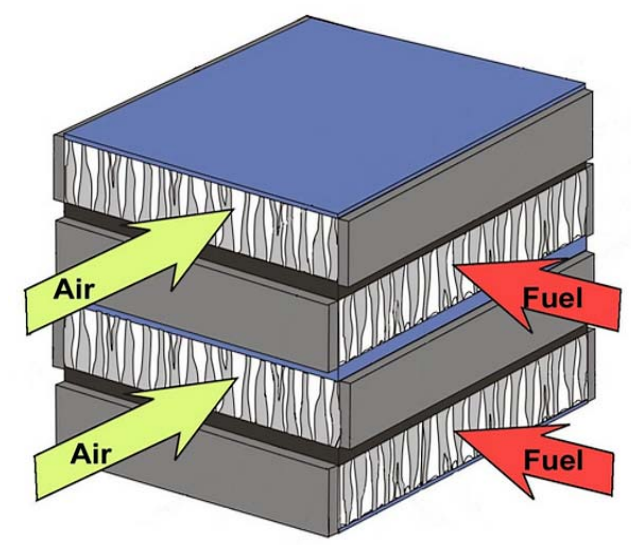

Figure 5. BSC X-flow stack design, thin black layer represents the YSZ electrolyte, the blue layer represents the $\mathrm{LaCaCrO}_{3}$ interconnect and the edge seals are shown in grey.

In 2007 and 2008 the focus of the fuel cell development program at NASA has been the investigation of regenerative SOFC performance. Higher operating temperatures favor regenerative or reversible solid oxide fuel cells (RSOFCs) for the electrolysis of $\mathrm{H}_{2} \mathrm{O}$ by decreasing the electrolyte resistance, increasing the electrode kinetics and decreasing the electrical energy required to split the water molecule. There are a number of terms used in the literature for SOFCs operating in reverse, including solid oxide electrolyzer (SOE), reversible fuel cells (RFC), unitized regenerative fuel cells (URFC) meaning both fuel cell and electrolysis are carried out in a single stack [6,7]. For most NASA applications the system of interest are regenerative SOFC (RSOFC), meaning that the system is "closed loop" and the reactants are regenerated and stored for use over and over again. When the term reversible is used, it means that for laboratory experiments the product $\mathrm{H}_{2}$ and $\mathrm{O}_{2}$ were simply exhausted and not stored. 
Although polymer electrolyte fuel cells are more advanced technologically, they are disadvantaged in electrolysis. The kinetics at the oxygen electrode are slow, resulting in a large activation energy barrier, requiring an increased step in voltage when going from fuel cell mode to electrolysis mode. In contrast, using an RSOFC, $\mathrm{H}_{2} \mathrm{O}$ electrolysis starts at just above the open circuit voltage (OCV), for example $1.0 \mathrm{~V}$. The PEM fuel cell may not initiate electrolysis until a voltage of $1.5 \mathrm{~V}$ is applied, thus reducing the achievable efficiency. With the PEM system there is the option of the electrolyzer and the fuel cell being combined into a "closed-loop" system, each stack optimized for the required conditions [8,9]. Employing RSOFC technology, a single unitized stack becomes possible reducing both weight and system complexity.

\section{EXPERMENTAL}

\section{Cell Fabrication and Electrochemical Testing}

Symmetrical BSC cells were fabricated by taking two green parts cut from the same freeze-tape cast substrates, depositing a thin electrolyte layer between the tapes, and laminating the tapes together with the small pores facing each other, forming the YSZ tri-layer. Symmetrical cells, with pinhole-free electrolytes, have been successfully fabricated as shown in Figure 4. Initial electrode infiltration techniques have used Ni-nitrates for the anode and stoichiometric solutions of Sr-doped $\mathrm{LaFeO}_{3}$ nitrates for the cathode. These nitrates were infiltrated into the YSZ electrode scaffold, without the use of a vacuum, and were allowed to dry/solidify prior to heat treatment in both air and reducing atmospheres for decomposition of the nitrates into metals or metal oxides, depending on the electrode. This infiltration procedure was performed multiple times on both the anode and cathode to achieve suitable electrode coverage as evaluated with SEM analysis. The final BSC is calcined at a temperature above $\simeq 850^{\circ} \mathrm{C}$ to ensure coalescence of materials from separate infiltration steps and conversion of the cathode to a predominantly perovskite phase. Figure 6 is a high resolution scanning electron micrograph of a tested, porous YSZ electrode scaffold, infiltrated with active Ni electrode. 


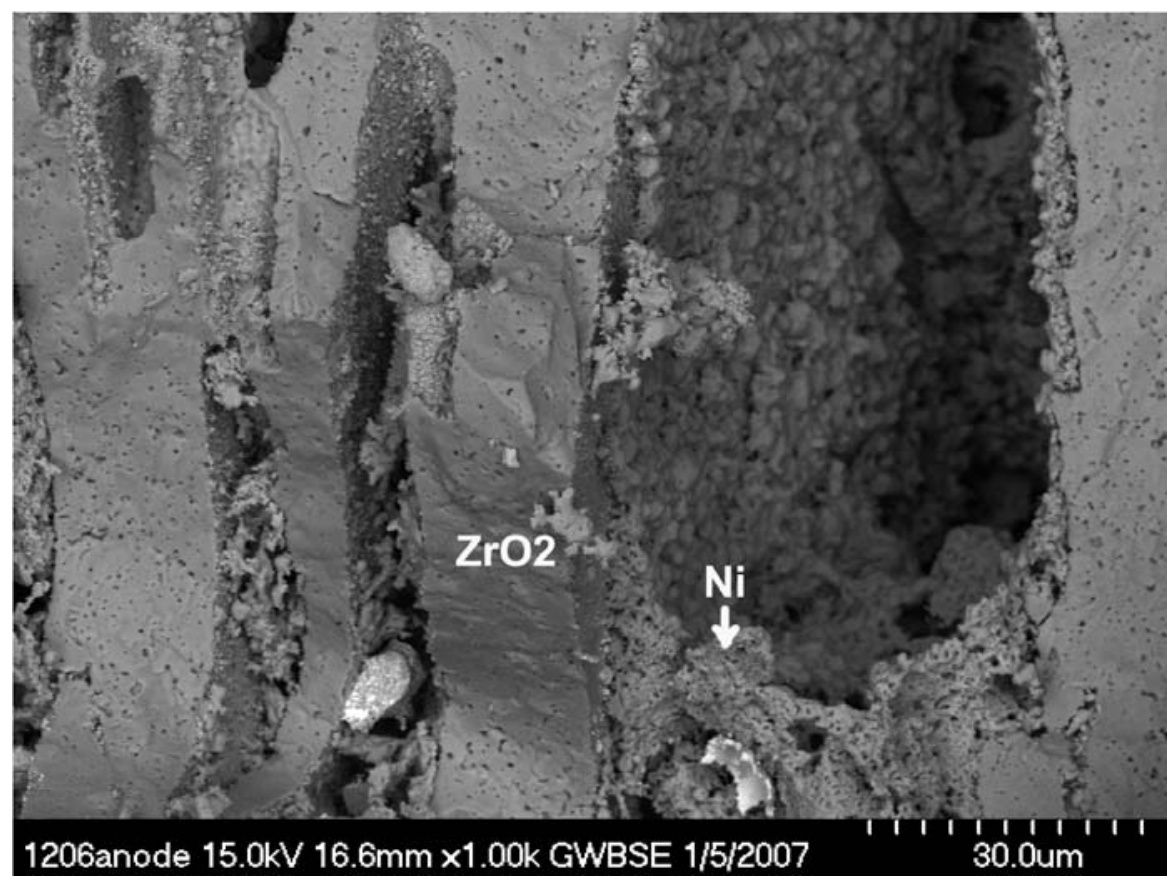

Figure 6: $\mathrm{BSC} \mathrm{Ni} / \mathrm{H}_{2}-\mathrm{H}_{2} \mathrm{O}$ electrode, after testing in electrolysis mode. SEM of region adjacent to the electrolyte showing Ni electrode adherent to and complete coverage of YSZ scaffolds.

Cell testing is conducted using the fixture geometry shown in Figure 7 . A cell $4.7 \mathrm{~cm}$ in diameter is set between two metal plates, each with a hole in the center for gas feed. The metal plates act as gas manifolds and current collectors, with current connection made outside the hot zone of the furnace using heavy gauge wire. At the cathode, silver-mesh is used as a current collector and is attached to the cell with gold ink. On the anode, nickel-mesh is used as the current collector and contact is made also made with gold ink. A thin platinum-wire is placed between the cell and current collectors to measure the voltage drop across the cell. The cells are heated to $700^{\circ} \mathrm{C}$ with air one side, forming gas $\left(5 \% \mathrm{H}_{2}: 95 \% \mathrm{~N}_{2}\right)$ the opposite. Once the cell reaches $700^{\circ} \mathrm{C}$ the anode gas is switched to $50 \% \mathrm{H}_{2}: 50 \% \mathrm{~N}_{2}$, with the gases controlled through separate flow controllers. The hydrogen is fed through a water saturator at room temperature. The air flow rate is set to four times the fuel flow rate. The cell is heated to $750^{\circ} \mathrm{C}$ and the cell is allowed to equilibrate at open circuit conditions at this temperature. A voltage-current scan (V-I) is performed from open circuit voltage $\left(\mathrm{V}_{\text {oc }}\right)$ to a voltage of $0.4 \mathrm{~V}$ in increments of $50 \mathrm{mV}$ and then back up to $\mathrm{V}_{\text {oc. }}$ This is repeated at $750^{\circ} \mathrm{C}, 800^{\circ} \mathrm{C}, 850^{\circ} \mathrm{C}$, and occasionally at $900^{\circ} \mathrm{C}$ depending on the purpose of the cell test.

To conduct electrolysis, a steam generator (Lyntech Humidifier) is added and a steam and $\mathrm{H}_{2}$ mixture is fed to the $\mathrm{Ni} / \mathrm{H}_{2}-\mathrm{H}_{2} \mathrm{O}$ electrode. Cells were tested at $15 \%, 25 \%, 35 \%$ and $50 \% \mathrm{H}_{2} \mathrm{O}$ by volume ratio to the $\mathrm{H}_{2}$ in both electrolysis and fuel cell mode. Once the $\mathrm{V}_{\text {oc }}$ of the cell had stabilized at each new condition, a voltage-current (VI) scan was performed on the cell, starting at $\mathrm{V}_{\text {oc }}$ and either stepping down in fuel cell mode or stepping up in electrolysis mode in $0.05 \mathrm{~V}$ increments, allowing the current to stabilize at each voltage setting. From the data, cell efficiencies and area specific resistances (ASRs) were calculated. Longer duration electrolysis tests were later performed at $90 \%$ and $95 \% \mathrm{H}_{2} \mathrm{O}$ under constant current conditions. 


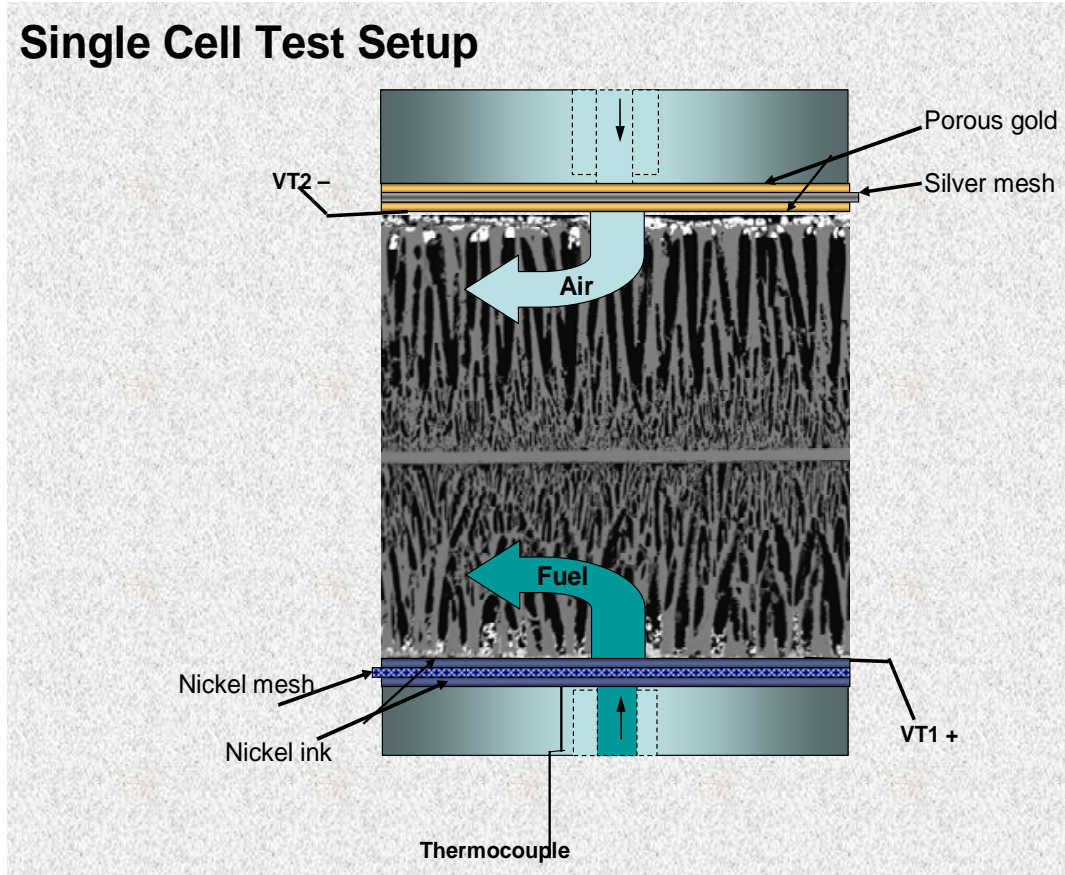

\section{Repeat Unit Test Setup}

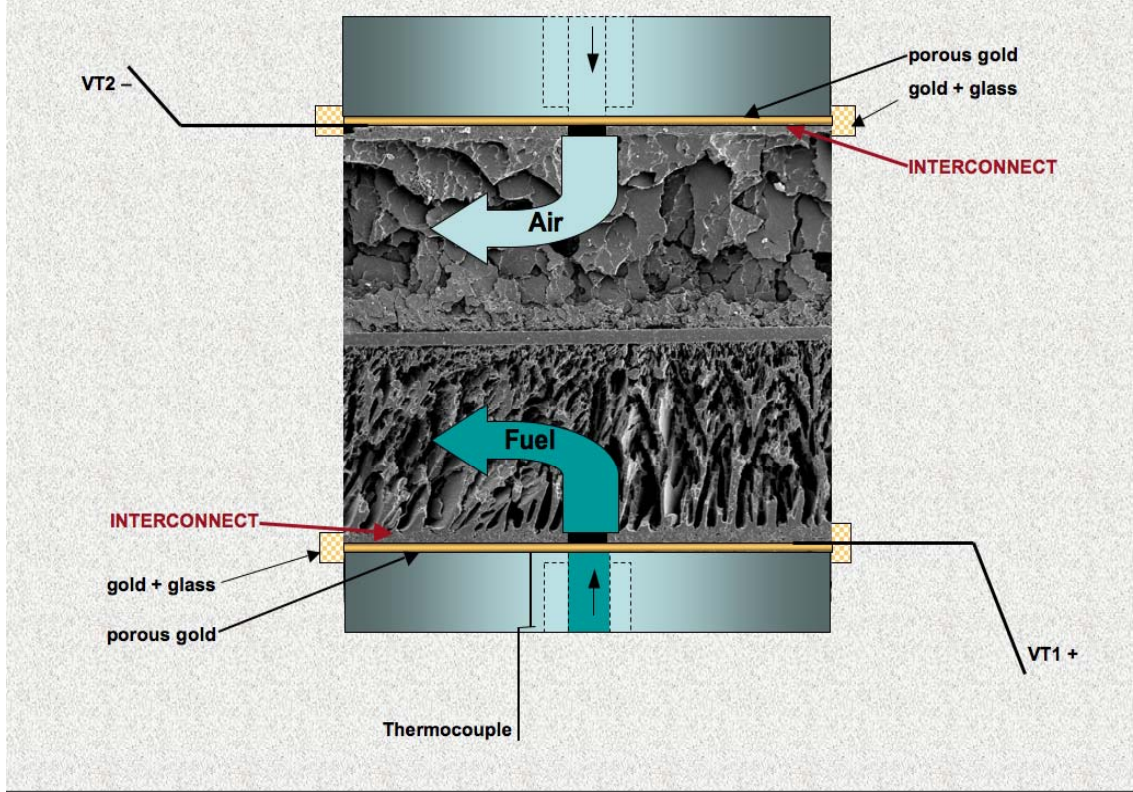

Figure 7. a.) Single cell fixture showing cell insertion and voltage leads. Fixture is enclosed in a clam-shell type furnace. b.) "Repeat Unit" fixture with $\mathrm{LaCrO}_{3}$ interconnects and showing $0-90^{\circ}$ of gas channels. (Cell microstructure and dimensions not to scale). 
In evaluating and comparing regenerative performance of different cells, the ASR and electrochemical voltage efficiency (EVE) was calculated. The efficiency is defined here as the ratio of the power generated in fuel cell mode to the power required to perform electrolysis, at constant current density as shown in equation (1) [8,9]. In a test under the same conditions while a VI scan is performed, the EVE is simply the ratio of the fuel cell voltage $\left(\mathrm{V}_{\mathrm{FC}}\right)$ to the electrolysis voltage $\left(\mathrm{V}_{\mathrm{EL}}\right)$ at a selected current density $\left(\mathrm{I}_{\mathrm{dens}}\right)$.

$$
\mathrm{EVE}=\mathrm{P}_{\mathrm{FC}} / \mathrm{P}_{\mathrm{EL}}=\left(\mathrm{VI}_{\mathrm{dens}}\right)_{\mathrm{FC}} /\left(\mathrm{VI}_{\mathrm{dens}}\right)_{\mathrm{EL}}=\mathrm{V}_{\mathrm{FC}} / \mathrm{V}_{\mathrm{EL}} @ \text { constant } \mathrm{I}_{\mathrm{dens}}
$$

\section{Results and discussion}

In 2005 and 2006 rapid progress was made in the performance of the BSC technology, as is shown in Figure 8. There were a number of improvements in fabrication that were responsible for the improved performance, including the quality of the electrolyte, the uniformity of the freeze-cast electrodes, the electrode infiltration process, and probably most importantly, the alignment and openness of the channels to improve gas diffusion.

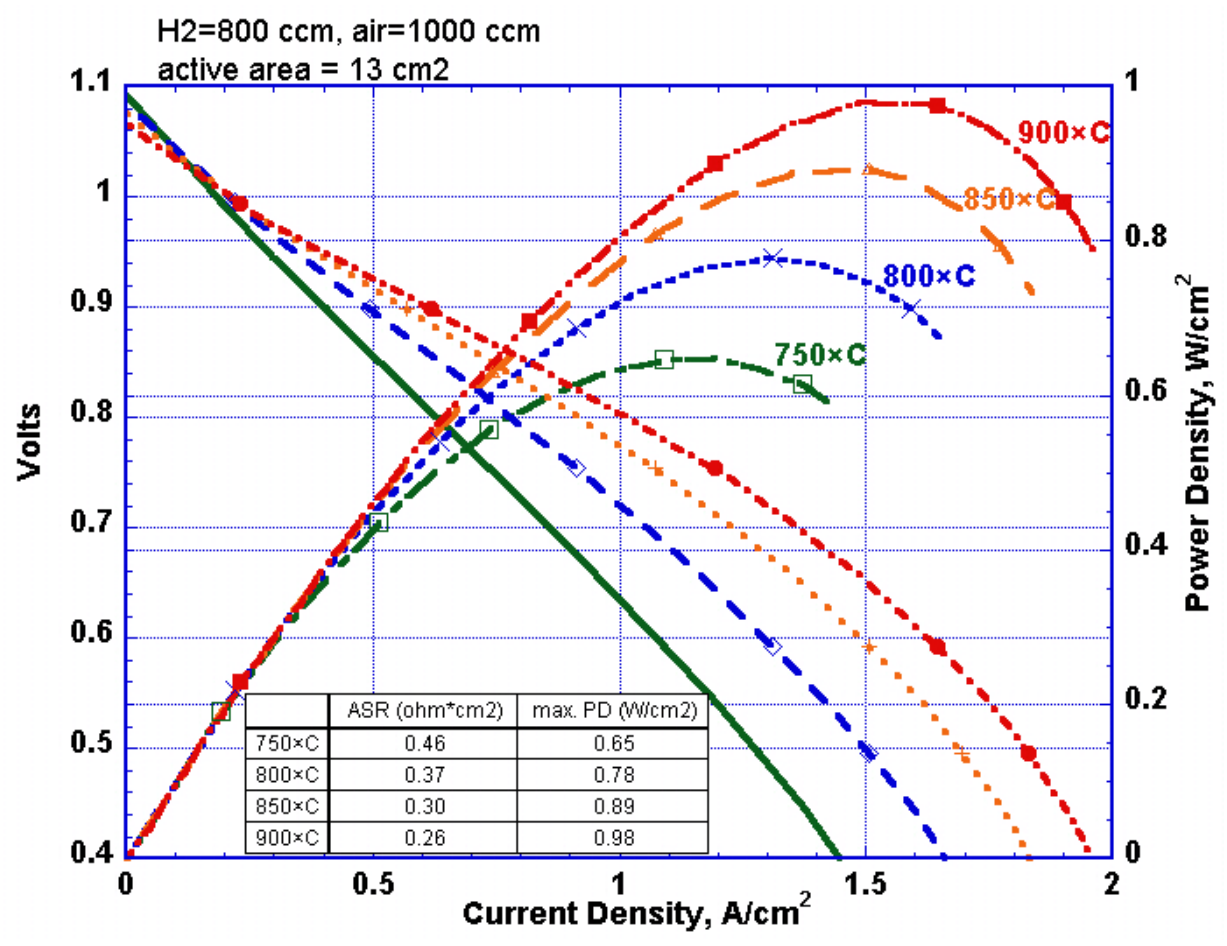

Figure 8. Early Improvement in BSC Performance (July 2006). 
A number of studies have been performed evaluating RSOFCs. The efficiencies (EVE) reported in the literature are generally in the range of $70 \%$ at $200 \mathrm{~mA} / \mathrm{cm}^{2}$ and $850^{\circ} \mathrm{C}$ and $83-85 \%$ at 100 $\mathrm{mA} / \mathrm{cm}^{2}$, depending on the water content of the feed gas $[5,8,9]$. NASA tests are performed under more stringent conditions than those normally reported in the literature for hydrogen production. NASA applications are directed toward UAVs and other aeronautic or space applications in which $\mathrm{H}_{2} / \mathrm{H}_{2} \mathrm{O}$ flow rates across the cells are much slower as is shown in Table 3 . Example data shown for Company $\mathrm{A}$ and $\mathrm{B}$ are for different cell designs and with the goal of commercially producing $\mathrm{H}_{2}$ only. In NASA's case, designing a $15 \mathrm{~kW}$ system for a UAV, hydrogen flow rates could be expected to be in the range of $8 \mathrm{cc} / \mathrm{min}$ for each $\mathrm{cm}^{2}$ of active fuel electrode area. Our testing was performed at $10 \mathrm{cc} / \mathrm{min}_{2}$ for each $\mathrm{cm}^{2}$ of fuel electrode area. What is encouraging is that we achieved high efficiencies at these low flow rates, without any modification to our standard cell design or electrode compositions.

\section{Table 3. Performance of BSC Design in Regenerative Operation}

Excellent efficiencies under expected operating conditions:

- Intermediate cell sizes tested

- Standard BSC cells, no modification to electrodes

- Low gas flow rates, simulating UAV closed system

\begin{tabular}{|c|c|c|c|}
\hline $\begin{array}{c}\text { Source } \\
\text { Data }\end{array}$ & $\begin{array}{l}\text { "Efficiency } \\
g^{0.1} \mathrm{\mu}^{\prime} \mathrm{cm}^{2} \\
(\%) \\
(\%)\end{array}$ & $\begin{array}{c}\text { Cell Area } \\
\left(\mathrm{cm}^{2}\right)\end{array}$ & $\begin{array}{l}\mathrm{H}_{2} \text { flow rate / Electrode Area } \\
\left.\qquad{ }^{*} \mathrm{sccm} / \mathrm{cm}^{2} \text { cell }\right) \\
\text { (USW a Nuck ar React.cold } \sim 8)\end{array}$ \\
\hline NASA GRC & 93 & 15.3 & 10 \\
\hline Company $\mathrm{A}$ & 83 & 10.0 & 30 \\
\hline Company B & 85 & 2.5 & 100 \\
\hline Company $\mathrm{B}$ & 45 & 60 & 8 \\
\hline
\end{tabular}

* ill data: Temp. $=850^{\circ} \mathrm{C}$ and $\mathrm{H}_{2}+\approx 50 \approx \mathrm{H}_{2} \mathrm{O}$

${ }^{*} \operatorname{sccm}=$ standard colmin

The RSOFC test in Figure 9 at $850^{\circ} \mathrm{C}$ shows the change in cell performance as the volume per cent $\mathrm{H}_{2} \mathrm{O}$ is varied from $50 \%$ to $15 \%$. At 50 volume per cent $\mathrm{H}_{2} \mathrm{O}$, the VI scan is fairly linear from $0.5 \mathrm{~A} / \mathrm{cm}^{2}$ in fuel cell mode, through the open circuit voltage, to about $-0.5 \mathrm{~A} / \mathrm{cm}^{2}$ in electrolysis mode before it starts to curve gradually up. Electrolysis continues out to a current density of $\sim-1 \mathrm{~A} / \mathrm{cm}^{2}$. The ASRs for these regions are $0.4 \mathrm{ohm}^{*} \mathrm{~cm}^{2}$ and $0.3 \mathrm{ohm}^{*} \mathrm{~cm}^{2}$ 
respectively. At the low $\mathrm{H}_{2} \mathrm{O}$ concentrations, 25 and 15 volume per cent, the cell becomes current limited or $\mathrm{H}_{2} \mathrm{O}$ starved, and this occurs at lower current densities for lower water concentrations. The cell has consumed the $\mathrm{H}_{2} \mathrm{O}$ and further increasing the voltage has little to no affect. The amount of water fed to the cell and the calculated maximum current correlated well with the experimental data obtained in these cell tests.

The current density has a much greater affect on efficiency than the per cent $\mathrm{H}_{2} 0$. Figure 10 compares results from two different cell tests and it can be seen that the slope of the lines for efficiency vary little as a function of per cent $\mathrm{H}_{2} \mathrm{O}$ at the lowest current density of $0.1 \mathrm{~A} / \mathrm{cm}^{2}$. An increase in current density makes a significant drop in the efficiency and the slope of the line is slightly greater, dropping off particularly at the low per cent $\mathrm{H}_{2} \mathrm{O}$ content where the cell starts to be water and diffusion limited.

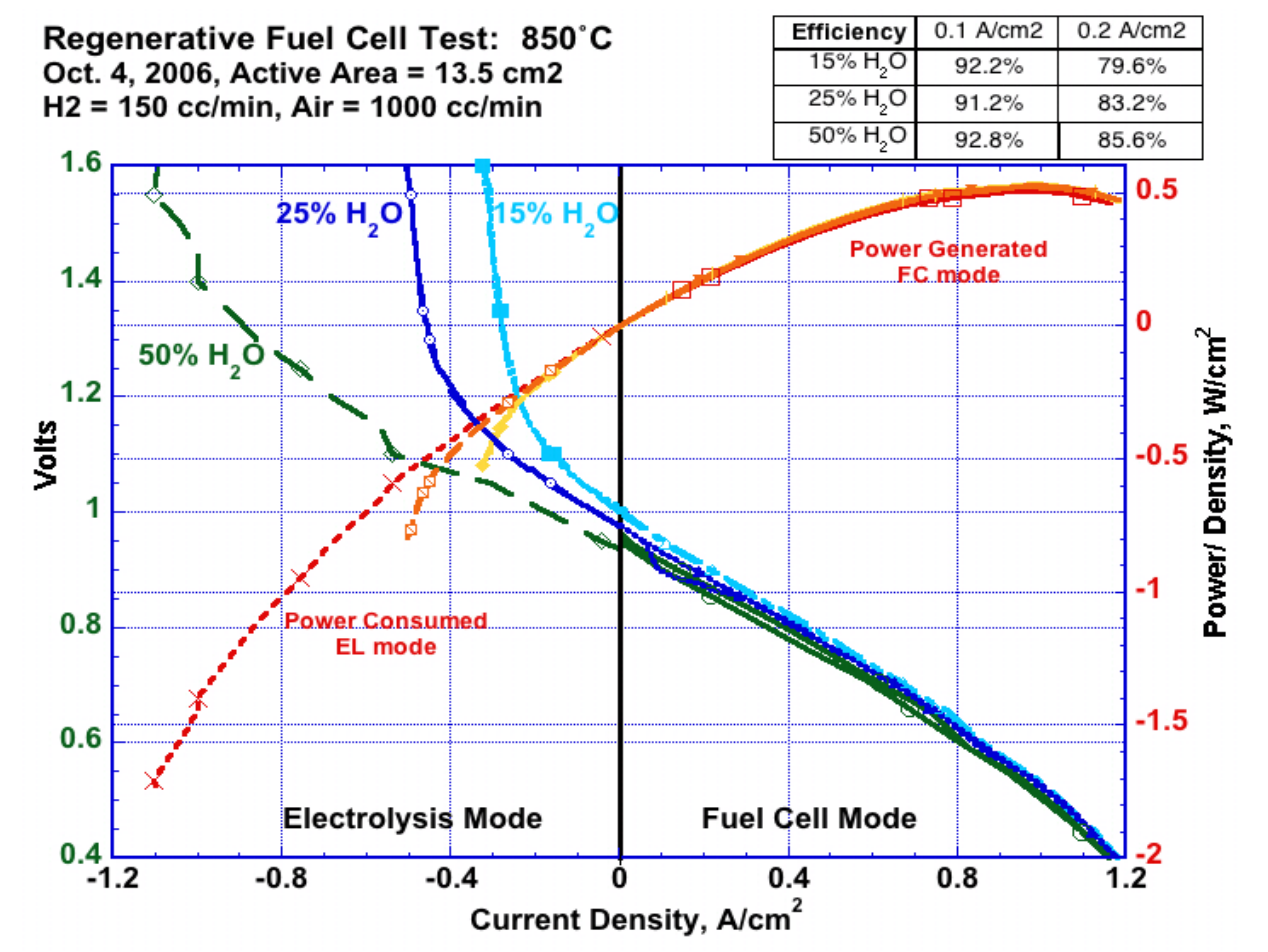

Figure 9. VI scan @ 850 ${ }^{\circ} \mathrm{C}$ vs. 15, 25, 50\% $\mathrm{H}_{2} \mathrm{O}$. Cell shows current limitation and signs of $\mathrm{H}_{2} \mathrm{O}$ starvation at 25 and $15 \% \mathrm{H}_{2} \mathrm{O}$ feed. 


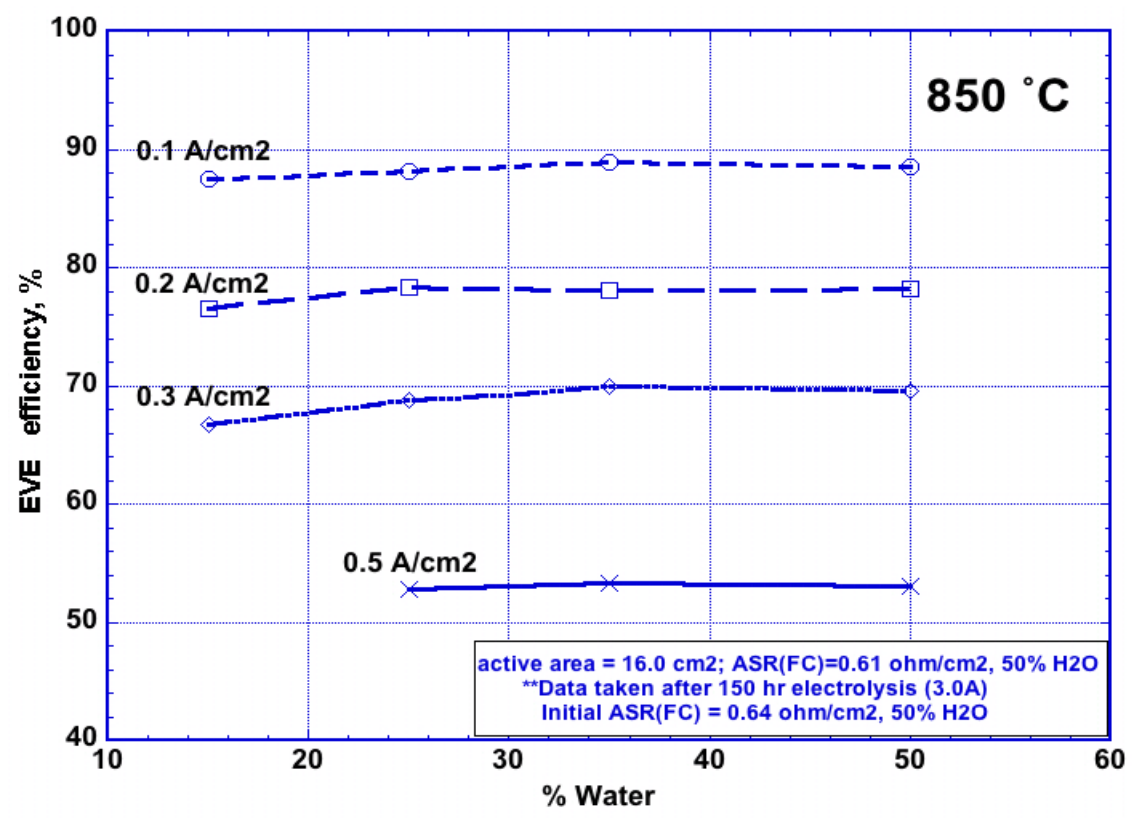

Figure 10. Electrochemical Voltage Efficiency vs. Current Density and $\% \mathrm{H}_{2} \mathrm{O}$ at $850^{\circ} \mathrm{C}$

In the regenerative or electrolysis conditions discussed earlier, where $\mathrm{H}_{2} \mathrm{O}$ flow rates are slow per $\mathrm{cm}^{2}$ of electrode area, it is important that $\mathrm{H}_{2} \mathrm{O}$ be able to diffuse in and out from the triple points or active sites at the electrode/electrolyte interface. This has been a major concern of the BSC design and the narrow channels in the freeze cast structure. Figure 11 shows electrolysis testing, under identical conditions, for four different BSC cells. The four cells show a significant difference in diffusion and performance. The first cell, shown by the black line, was fabricated early in our project and it shows current limitation behavior, similar to that in Figure 9, as if it is starved for $\mathrm{H}_{2} \mathrm{O}$, at a current density of $0.4 \mathrm{~A} / \mathrm{cm}^{2}$, even though only $40 \%$ of the $\mathrm{H}_{2} \mathrm{O}$ is converted. The cell has unconverted $\mathrm{H}_{2} \mathrm{O}$ available to achieve a current density of $>1.0 \mathrm{~A} / \mathrm{cm} 2$. The other three cells were fabricated with processing techniques specifically designed to improve electrode structure openness, making it possible for the cells to increase from $0.4 \mathrm{~A} / \mathrm{cm}^{2}$ to 1.4 $\mathrm{A} / \mathrm{cm}^{2}$ which is approximately $95 \%$ conversion of the water. The significant change in the microstructure of the electrodes for the cells tested in Figure 11 can be seen in the SEM in Figure 12. Freeze casting allows rapid modification of cell microstructures. Cell structure can be quickly and effectively tailored to meet application requirements relatively quickly compared with more complicated SOFC designs. 


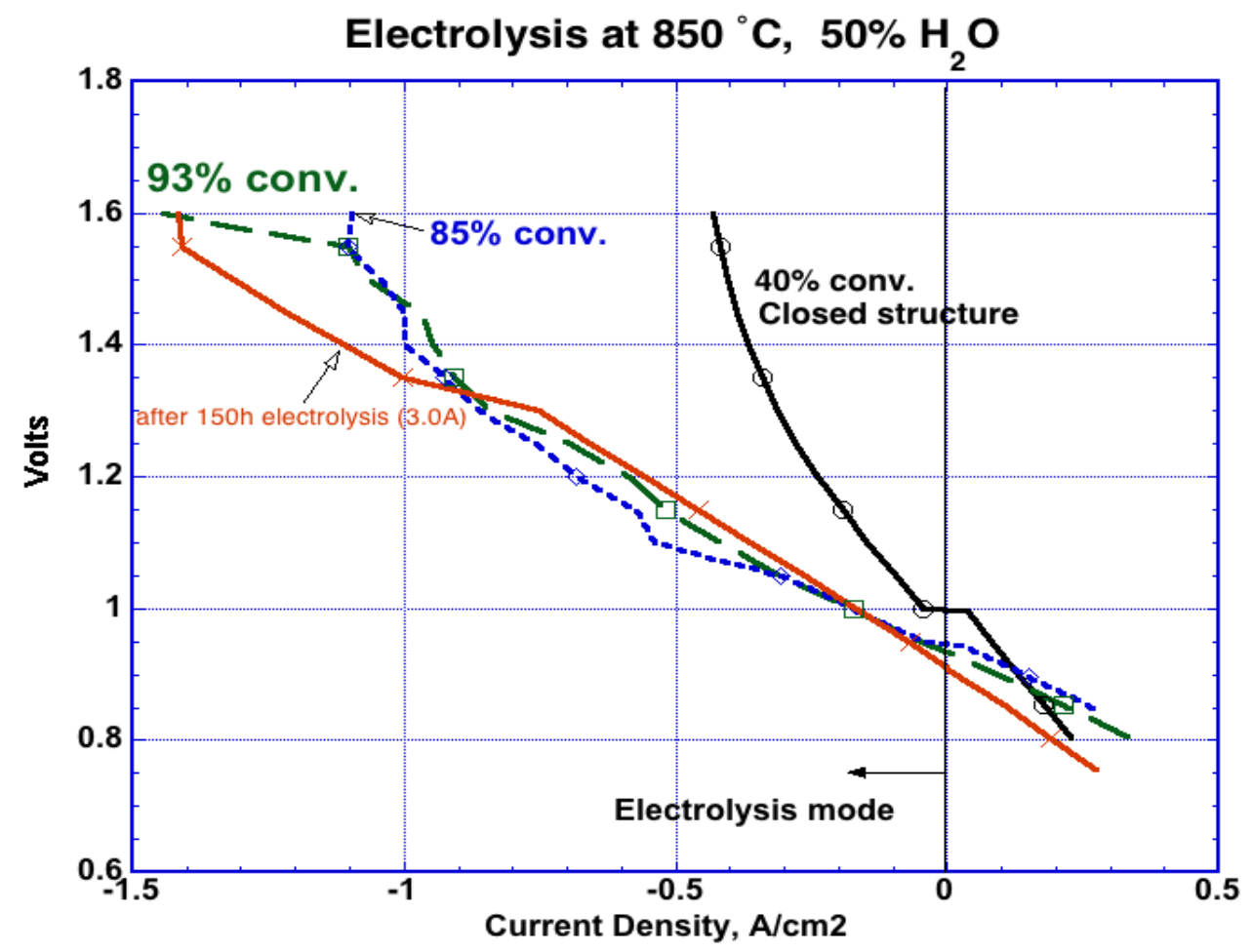

Figure 11. V-I scans for four cell tests, early cells with fine electrode microstructures were limited to $40 \% \mathrm{H}_{2} \mathrm{O}$ conversion, subsequent cell tests with open structures showed increased $\mathrm{H}_{2} \mathrm{O}$ diffusion and conversion.

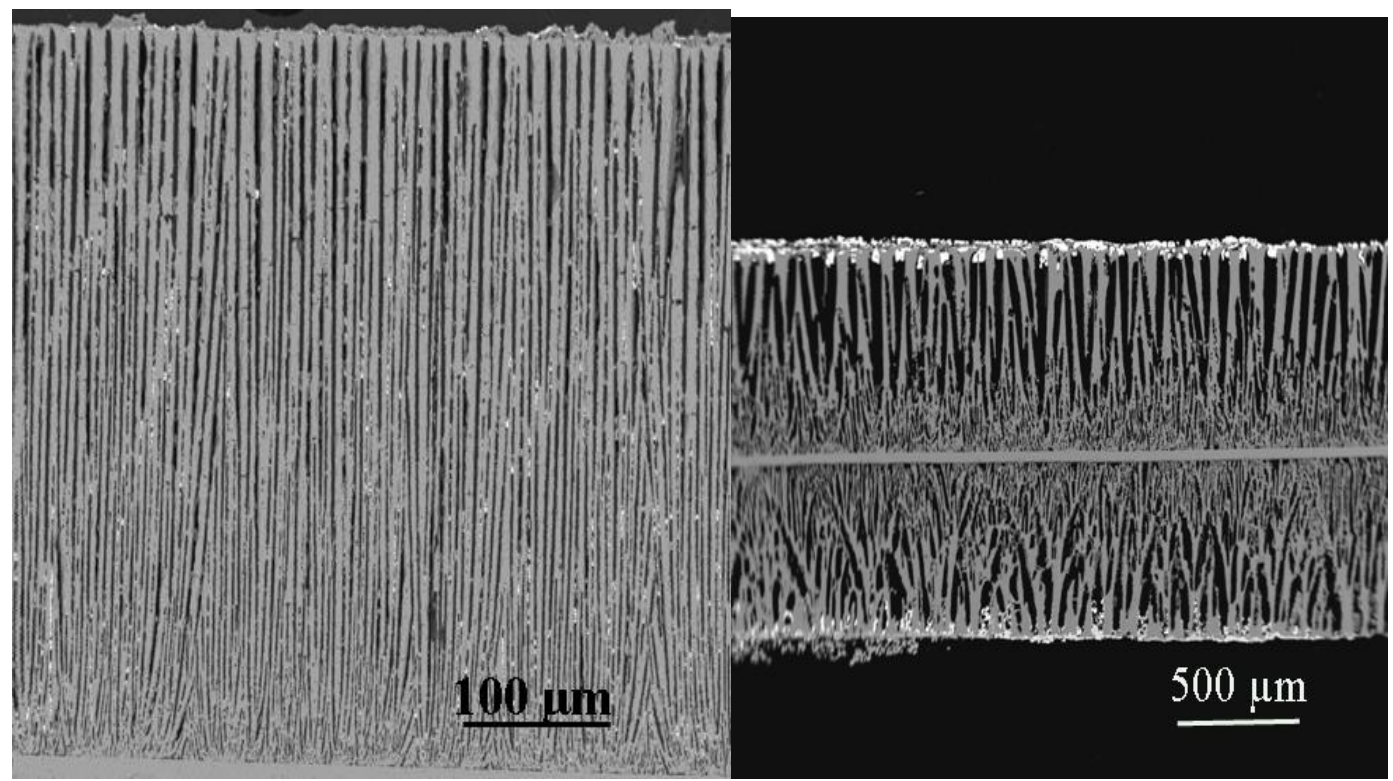


Figure 12. SEM of the $\mathrm{H}_{2} / \mathrm{H}_{2} \mathrm{O}$ electrode on the left, achieved only $40 \%$ conversion in electrolysis, it shows narrow channels; alteration of the freeze-cast parameters allowed the channels to be opened to promote better gas diffusion, as shown in the cell on the right which improved conversion to $95 \%$ under identical test conditions.

One of the concerns with the NASA design is the use of wet impregnation techniques for application of the active electrode materials. The Ni-anode was expected to be susceptible to sintering into larger grains at high temperature, particularly if the RSOFC is operated at temperatures as high as $900^{\circ} \mathrm{C}$. This problem might be lessened by the fact that the RSOFCs could operate at low current densities, in the range of 100 to $200 \mathrm{~mA} / \mathrm{cm}^{2}$. However, it would still be expected that temperature would be the stronger driving force for Ni-migration than current density.

There have been numerous reports in the literature concerning performance of SOEs [10 -13], most of them focusing on the $\mathrm{Ni} / \mathrm{H}_{2}-\mathrm{H}_{2} \mathrm{O}$ electrode. Unfortunately, the stability of the cells varies from showing essentially no degradation over a period of 1000 hours to degradations greater than $100 \%$. In some cases for constant electrolysis, cells have shown rapid degradation initially, followed by essentially no degradation. It was reported in one study [12] that operation in fuel cell mode for a brief period, following passivation in electrolysis, resulted in activation of the cell upon return to electrolysis mode and gradually reduced cell resistance. In another study LSM was specifically identified as being a source of degradation in electrolysis, resulting in delamination [13]. However, no delamination was observed with LSF and LSCF oxygen electrodes. In that same study the cell experienced similar degradation, regardless of whether it was operated in constant Fuel Cell, constant Electrolysis, or Reversible mode of operation.

Although NASA is limited to one electrolysis or regenerative test stand, a number of life tests were performed; a summary of the tests is given in Table 4. Test A was performed under conditions of constant electrolysis and the cell showed no degradation in performance. In fact, it showed a very slight improvement in overall performance. Cell Test B was operated in constant Regenerative Mode, alternating back and forth from FC to EL Mode. Cell B showed rapid degradation and both FC and EL performance were equally affected at 30\% to 33\% degradation each. A repeat of Test B, with an identical cell, Cell Test $\mathrm{C}$, again showed high degradation in EL mode but almost no degradation in the FC performance. Post examination by SEM of cells B and $\mathrm{C}$ showed no observable difference that would easily explain why one would degrade in FC Mode and the other would not.

The last life study shown in Table 4, Cell Test D, was the longest, over 600 hours, but the test experienced technical difficulties as shown in Figure 13. Early in the test it experienced a pump failure over a weekend while in EL Mode, so that a potential was applied to the cell but no $\mathrm{H}_{2} \mathrm{O}$. The cell recovered and after completion of 160 hours operation in Regenerative mode the cell showed no sign of degradation in FC mode but $27 \%$ degradation in the EL Mode, very similar to Cell C in Table 4. The cell was then tested in constant electrolysis for a period of 90 hours and it showed low degradation of about $6 \%$, similar to that of Cell A. Unfortunately at this point in the life study (240 hours) the test had another water outage and upon returning to a Regenerative Mode of operation, the degradation of the cell accelerated in both modes, 37\% in EL and 21\% in 
FC, somewhat similar to Cell Test B. In the last stage of the life test, Cell D was operated in constant EL for 285 hours and experienced a degradation of 9\%, still fairly low, and it appeared the degradation rate was decreasing after the cell had reached 500 hours.

There are not enough cell tests in Table 4 to come to any firm conclusions, but it highlights the need for focused studies to determine which electrode is dominating degradation and the degradation mechanism(s). The tests seem to indicate that it is possible for a cell to operate with little or no degradation when in constant electrolysis mode. However, the EL performance degrades as soon as it is put in a regenerative mode of operation. This result is very different from those reported in the literature [13], in other studies investigating performance in both electrolysis and regenerative operation, the cells in constant electrolysis mode showed high degradation, and as high as when operated in the regenerative mode, with degradations as high as 200\% per 1000 hours for both constant electrolysis and regenerative operation. In the BSC studies shown in Table 4, the results for the FC performance in Regenerative Mode of operation were inconsistent, some cell tests showed high degradation (Cell B) and in others they showed no degradation (Cell C \& D). However, even the cases of high degradation, 33\% per 1000 hours, are significantly lower than the $200 \%$ reported in the literature [13]. In those studies the major source of degradation was attributed to the cathode. Development of a new cathode, LSCF, lowered the degradation rate in Regenerative Mode from approximately $220 \%$ to $180 \%$ in EL, and down from $170 \%$ to $45 \%$ in FC. Finally, the research team used an SDC barrier on the oxygen electrode and porosity engineering on the $\mathrm{H}_{2}$ electrode, the EL degradation was reduced to the $40-50 \%$ range [13].

In some early BSC electrolysis tests microscopy of the fuel electrode revealed some signs of $\mathrm{Ni}$ agglomeration at the top of the cell, near the current collector, away from the electrolyte interface where it may have no affect on cell performance to any great extent. Post analysis of Cell D, operated for a total of 600 hours in both regenerative and electrolysis modes of operation, was performed by SEM; both fracture samples and polished cross-sections were examined. The SEM of the anode adjacent to the electrolyte was shown in Figure 6 and showed a continuous coating of Ni-electrode on the walls of the YSZ scaffold or channels, and a uniform Ni particle size. When Ni particle size was compared at the electrolyte interface with particles away from the electrolyte, there was no obvious evidence of Ni-agglomeration in any regions that would give an indication for Ni particle size leading to a degradation of performance. However, recent qualitative studies in Europe show subtle but measurable microtsructural changes in the $\mathrm{Ni}$, accompanied with impurities [15]. Examination here was not as detailed.

Table 4. NASA Life Studies - Electrolysis and Regenerative Cell Performance

\begin{tabular}{|c|c|c|c|}
\hline Cell Test & $\begin{array}{c}\text { Time on Stream } \\
\text { (hours) }\end{array}$ & $\begin{array}{c}\text { Degradation } \\
\mathbf{( \% / 1 0 0 0 ~ h r )} \\
\text { EL Mode }\end{array}$ & $\begin{array}{c}\text { Degradation } \\
\text { (\%/ 1000 hr) } \\
\text { FC Mode }\end{array}$ \\
\hline A & 166 (EL Only) & $0 *$ & \\
\hline B & 320 & 30 & 33 \\
\hline C & 320 & 24 & 1 \\
\hline & & & \\
\hline
\end{tabular}




\begin{tabular}{|c|c|c|c|}
\hline D & 160 & 27 & 0 \\
\hline & 90 (EL Only) & 6 & 21 \\
\hline & 80 & 37 & \\
\hline
\end{tabular}

*Note: Cell actually showed slight improvement in performance.

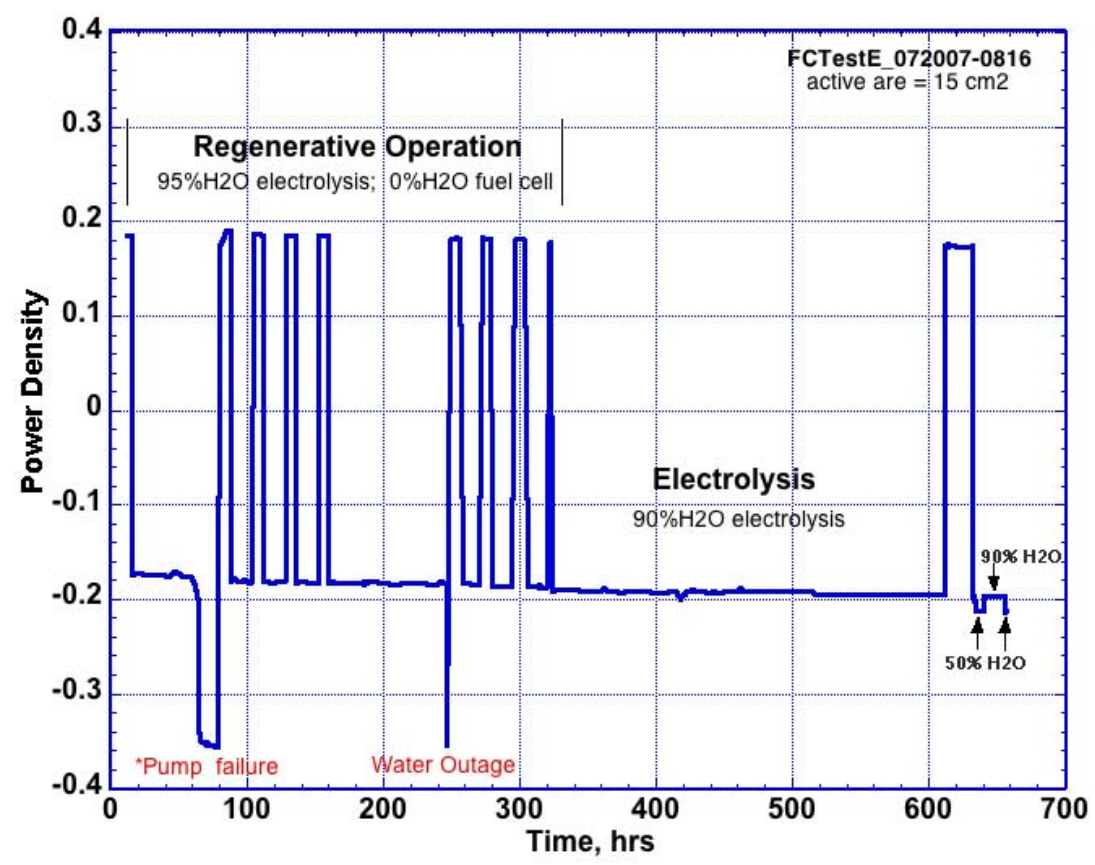

Figure 13. Life test over 650 hours (Cell D, Table 4) at constant current density $\left(200 \mathrm{~mA} / \mathrm{cm}^{2}\right)$; shows increased rate of degradation in regenerative mode, lower degradation in constant electrolysis.

\section{CONCLUSIONS AND FUTURE WORK}

The NASA BSC shows good performance and high efficiency in single cell tests of $15 \mathrm{~cm}^{2}$ active area, even under stringent low flow rate conditions considered applicable to UAVs and much lower than expected for systems designed for $\mathrm{H}_{2}$ production. Efficiencies are high enough that it does not warrant immediate further study on electrode compositions, however, the focus should be on electrode microstructure, with particular emphasis on long-term stability. Ni and LSCF electrodes fabricated for SOFC power generation were tested without optimization in this study. Life studies, particularly in the regenerative mode with cycling from electrolysis to fuel cell mode needs to be investigated. Alternate compositions may be required to extend the operation in regenerative environments.

Efforts to improve the gas flow channels and diffusion in the electrode support structures was shown to be very beneficial, increasing $\mathrm{H}_{2} \mathrm{O}$ conversion from $40 \%$ to greater than $90 \%$. For 
applications where flow rates will be higher, NASA has started work on micro-channels which will be incorporated into the electrodes, a subject that will be addressed in future papers.

\section{References}

1. S. Atreya, M. Mata, R. Jones and L. Kohout, "Power System Comparisons for a High Altitude Long Endurance (HALE) Remotely Operated Aircraft (ROA)”, AIAA $5^{\text {th }}$ Aviation, Technology, Integration and operations Conference, Arlington, VA, Sept. 26-28, 2005.

2. C.J. Steffen, J.E. Freeh, L.M. Larosiliere, "Solid Oxide Fuel Cell/Gas Turbine Hybrid Cycle Technology for Auxiliary Aerospace Power”, Proceedings of ASME Turbo Expo 2005: Power for Land, Sea, and Air, June 6-9, 2005, Reno-Tahoe, Nevada.

3. J. Zizelman, “Development Update on Delphi's Solid Oxide Fuel Cell System,” Presented at $4^{\text {th }}$ SECA Conf., Seattle, WA, April 15-16, 2003.

4. T. Cable and S. Sofie, "A Symmetrical, Planar SOFC Design for NASA's High Specific Power Density Requirements”, Journal of Power Sources 174 (2007) 221-227.

5. S. Sofie and F. Dogan, "Freeze Casting of Aqueous Alumina Slurries with Glycerol”, J. Am. Ceram. Soc., 84 (7) 1459-69 (2001).

6. F. Mitlitsky, B. Myers and A. Weisberg, "Regenerative Fuel Cell Systems”, Energy \& Fuels 1998, 12, 56-71.

7. H. Uchida, N. Osada and M. Watanabe, "High-Performance Electrode for Steam Electrolysis”, Electrochemical and Solid-State Letters, 7 (12) A500-A502 (2004).

8. F. Barbir, L. Dalton and T. Molter, "Regenerative Fuel Cells for Energy Storgae: Efficiency and Weight Trade-offs”, $1^{\text {st }}$ Inter. Energy Conv. Engineering Conf., 17-21 Aug., 2003, Portsomouth, VA.

9. U. Wittstadt, E. Wagner, T. Jungman, "Membrane Electrode Assemblies for Unitised Regenerative Polymer Electrolyte Fuel Cells”, Journal of Power Sources, 145 (2005) 555-562.

10. D. Hickey, M. Cassidy, J. McElroy, F. Mitlitsky, and V. Venkataraman, "Optimization and Demonstration of a Solid Oxide Regenerative Fuel Cell System”, SOFC-IX, 285-294, Quebec City, Canada, May 15-20, 2005.

11. J.S. Herring, P. Lessing, J. O’Brien, C. Stoots and J. Hartvigsen, "Hydrogen Production through High-Temperature Electrolysis in a Solid Oxide Cell," Second Information Exchange Meeting on Nuclear Production of Hydrogen, Argonne National Laboratory, Illinois, October 23, 2003.

12. A. Hauch, S.H. Jensen, S. Ramousse, and M. Mogensen, "Performance and Durability if Solid Oxide Electrolysis Cells”, J. Electrochemical Soc., 153 (9) A1741 (2006).

13. J. Guan, B. Ramamurthi, J. Ruud, J. Hong, P. Riley, D. Weng, N. Minh, "High Performance Flexible Reversible Solid Oxide Fuel Cell”, GE Global Research, DOE Final Report, October 2004-November 2006, www.osti.gov/bridge/servlets/purl/899650-fhtqgi/.

14. J. Carter, et al., "Post Test Evaluation of The Oxygen Electrode from a Solid Oxide Electrolysis Stack and Electrode Materials Development”, http://aiche.confex.com/aiche/2007/techprogram/P96599.HTM.

15. A. Hauch, S.D. Ebbesen, S. H. Jensen, and M. Mogensen, "Solid Oxide Electrolysis Cells: Microstructure and Durability of the Ni/Yttria-Stabilized Zirconia Electrode”, J. Electrochemical Soc., 155 (11) B1184 (2008). 